\title{
[3 + 2] Cycloaddition reactions of thioisatin with thiazolidine-2-carboxylic acid: a versatile route to new heterocyclic scaffolds
}

\author{
Sonali Verma, Johnson George, Saurabh Singh, Pushpa Pardasani and Ramchand Pardasani
}

\begin{abstract}
A facile synthesis of azabicycloadducts is described by 1,3-dipolar cycloaddition reactions of thioisatin with thiazolidine-2-carboxylic acid in the presence of various electron rich and electron deficient dipolarophiles. Theoritical calculations have been performed to study the regioselectivity of products. The geometrical and energetic properties have been analyzed for the different reactants, transition states and cycloadducts formed.
\end{abstract}

Keywords: Azabicycloadducts, 1,3-Dipolar cycloaddition reactions, AM1 Calculations, Thioisatin, Thiazolidine-2-carboxylic Acid

\section{Background}

The construction of sophisticated molecules requires viable, selective and highly reliable reactions as potent synthetic tools [1-3]. The 1,3-dipolar cycloaddition [4-9] has also become one of the most important legation method in biology and material chemistry. Thioisatin derivatives [10] have received the attention of biochemists because of their therapeutic and biological activities. Similarly thiazolidine-2-carboxylic acid [11,12] exhibit strong antioxidant properties. Therefore any heterocyclic scaffold containing these two moieties might be expected to have considerably enhanced biological activities.

The 1,3-dipolar cycloaddition reaction of an azomethine ylide with an alkene leads to the formation of pyrrolidine $[13,14]$ derivatives. Recently, we have reported the results on azomethine ylides derived from 9,10-phenanthrenequinone and some secondary cyclic $\alpha$-amino acids with different dipolarophiles [15]. Herein we report the reactivity and regioselectivity of 1,3-dipolar cycloaddition reactions of azomethine ylides derived from benzo[b]thiophene-2,3-dione with thiazolidine-2carboxylic acid in the presence of various acetylenic and ethylenic dipolarophiles. Besides synthetic work, a systematic and comprehensive theoretical study at Gaussian 03 [16] suite of programs has been carried out to

\footnotetext{
* Correspondence: rtpardasani@gmail.com

Department of Chemistry, University of Rajasthan, Jaipur - 302 055, INDIA
}

address the mechanism as well as regio- and stereochemical course of the reactions.

\section{Result and discussion}

The reaction of thioisatin 1 with thiazolidine-2-carboxylic 2 acid was carried out in equimolar ratio in refluxing dry acetonitrile in the presence of diphenylacetylene as dipolarophile to afford a diastereomeric mixture of $\{(5 R, 8 R)$-spiro-6,7-diphenyl-1aza-4thia-bicyclo [3,3,0]-6-octene-8,3'\}-benzo[b]thiophene-2'-one\} 8 as cis/ trans isomers. Analogous reactions of thioisatin with other dipolarophiles viz methyl acrylate, phenylacetylene, phenylpropyne and ethyl phenyl propiolate produced diasteroisomeric mixtures of cycloadducts 5-9 in 75\%$63 \%$ yield. The mechanism for the formation of the cycloadducts 5-9 involve the initial formation of an iminium species 3 followed by the loss of $\mathrm{CO}_{2}$ via stereospecific 1,3-cycloreversion [17] to azomethine ylides 4 . Subsequent $[3+2]$ cycloaddition with various dipolarophiles then produce novel azabicycloadducts (Scheme 1).

The structure of all the cycloadducts has been ascertained from their spectral data. Thus the IR spectrum of a typical diphenylacetylene cycloadducts 8 showed characteristic bands at 1715, 1420 and 690 for $>C=\mathrm{O}, \mathrm{C}$ $\mathrm{N}$ and $\mathrm{C}-\mathrm{S}$ stretching vibrations respectively. Its ${ }^{1} \mathrm{H}$ NMR spectrum showed a triplet at $\delta 2.51(J=2.7 \mathrm{~Hz})$ for $3 \mathrm{H}$ protons, another triplet at $\delta 2.60(\mathrm{~J}=3.0 \mathrm{~Hz})$ was associated with $2 \mathrm{H}$ protons, a singlet at $\delta 4.15$ appeared 

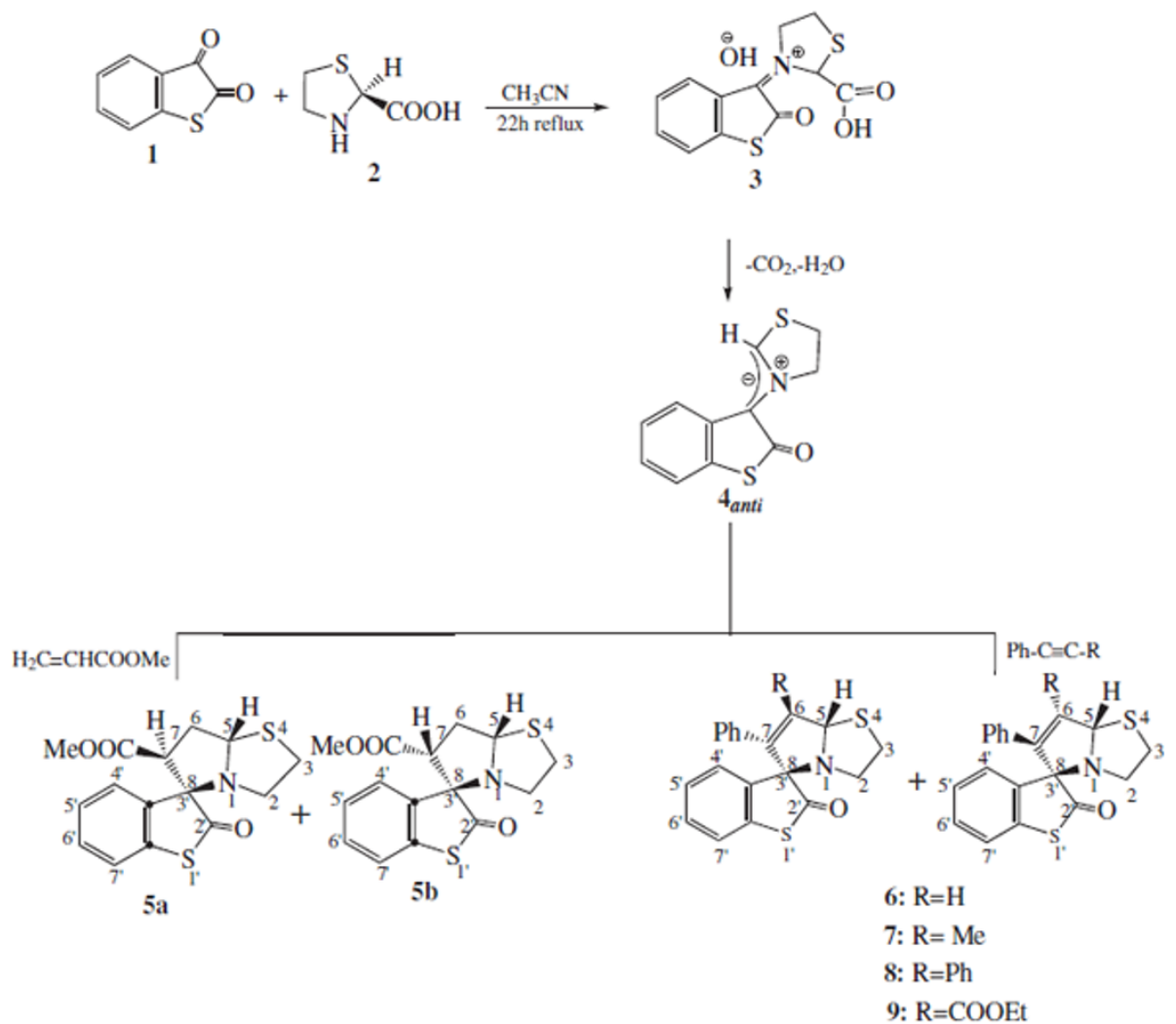

Scheme 1 Reaction of thioisatin with thiazolidine-2-carboxylic acid in presence of different dipolarophiles produced regioisomeric mixtures of cycloadducts.

for $5 \mathrm{H}$ and the aromatic protons resonated between $\delta$ 6.79- $\delta 8.12 \mathrm{ppm}$. Its ${ }^{13} \mathrm{C}$ NMR spectrum showed a signal at 183.54 for C-2' carbonyl carbon, aromatic carbons appeared in the range $\delta 146.41-\delta 131.32 \mathrm{ppm}$, the olefenic carbons (C-6, C-7) resonated at $\delta 127.32$ and 126.54, spiro carbon (C-8) was noticed at $\delta 86.23, \mathrm{C}-5$ at $\delta$ $46.72, \mathrm{C}-2$ at $\delta$ 45.43, and C-3 at 34.56 ppm respectively. Additional evidence was gathered from the mass spectrum of cycloadduct 8 . The molecular ion and the base peaks were present at $\mathrm{m} / \mathrm{z} 413(32 \%)$ and $235(100 \%)$ respectively; another peak at $\mathrm{m} / \mathrm{z} 385(39 \%)$ corresponded to $[\mathrm{M}-\mathrm{CO}]^{+}$whereas the peak at $\mathrm{m} / \mathrm{z} 108(35 \%)$ was assigned to $\left[\mathrm{C}_{6} \mathrm{H}_{4} \mathrm{~S}\right]^{++}$.

\subsection{Theoretical calculations: Regioselectivity of cycloadducts 5-9}

The stereochemical course of the cycloaddition was examined by AM1 calculations. To calculate the relevant activation and stabilization energies, minimized geometries of the reactants, products and transition states are required. The molecular geometry of the simplest azomethine ylide (abbreviated as amy) 4 derived from thioisatin and thiazolidine-2-carboxylic acid has been optimized on Gaussian 03 program at AM1 level.
Geometry optimization showed that amy $\mathbf{4}$ has almost planar structure (Figure 1). Instead of having an envelope shape the thiazolidine ring is planar and lies in the same plane as that of thioisatin ring. It may exist in two isomeric forms, one in which $>\mathrm{C}=\mathrm{O}$ group and $\mathrm{C}-\mathrm{H}$ of the dipole are $s y n$ to each other, $\mathbf{4}_{\text {syn }}$, and the other in which these two groups are anti, $\mathbf{4}_{\text {anti }}$ (Figure 2).

Methyl acrylate may approach either of the amy with the formation of products having three chiral centers.

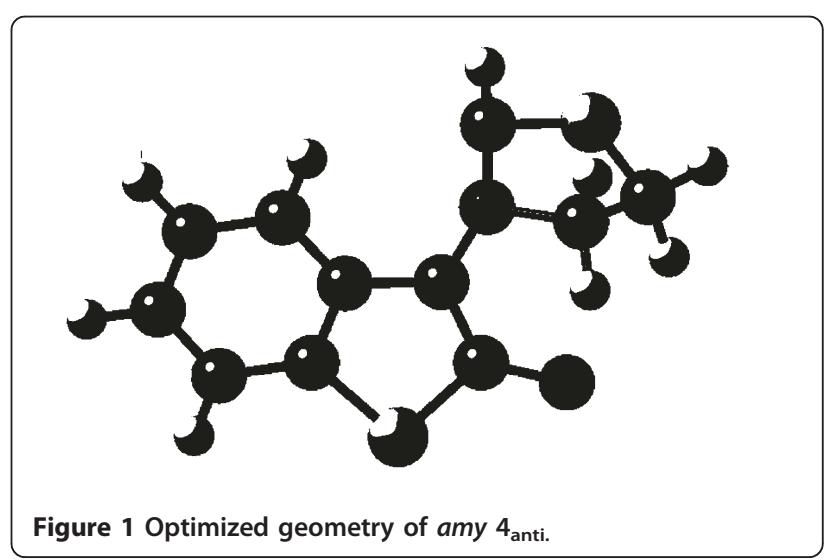



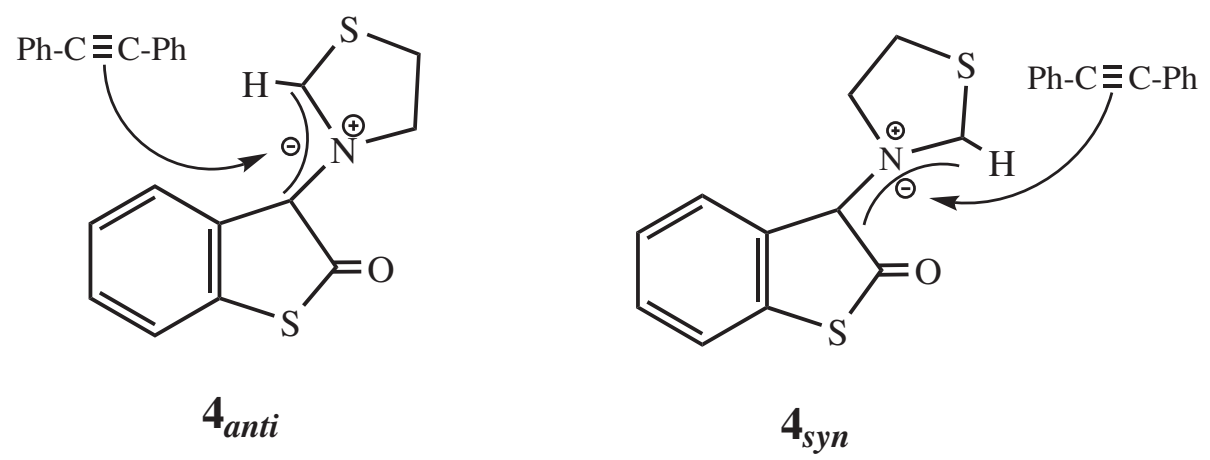

Figure 2 Mode of attack of dipolarophile (diphenylacetylene) on amy 4.

Therefore a total $8+8=16$ isomers $\mathbf{5 a - 5 p}$ are possible (Figure 3).

Attack of methyl acrylate on syn amy results in the inward movement of thiazolidine ring towards thioisatin nucleus which imposes steric hindrance and makes it unstable. In fact we failed to locate the transition state in any such case $\mathbf{5 i - 5 p}$. The remaining 8 isomers may be obtained by the attack of methyl acrylate on anti amy. Out of these 8 possibilities only four $\mathbf{5 a - 5 d}$ have concerted mechanism. We have optimized the geometries of all the four isomers. Results show that all isomers have almost same $\Delta H_{\mathrm{f}}$, indicating that thermodynamically all are nearly equally stable.

We have carried out transition state calculations on all the four isomers but have been successful in locating the transition state for only two isomers $\mathbf{5 a}-\mathbf{5 b}$ (Figure 4).

The transition state of the concerted 1,3-dipolar cycloadditions is usually controlled by frontier molecular orbitals of dipolarophiles and dipole (azomethine ylide). The favoured path involves $\mathrm{HOMO}_{\text {dipole }}$ and $\mathrm{LUMO}_{\text {dipo- }}$ larophile. The $\Delta H_{\mathrm{f}}, \mathrm{HOMO}, \mathrm{LUMO}$ energies and HOMO-LUMO energy gaps of azomethine ylides 4 with dipolarphiles are given in Table 1.

From the Table, it may be concluded that $\mathrm{HOMO}_{\text {di- }}$ pole-LUMO $\mathrm{O}_{\text {dipolarophile }}$ energy gap is lower than the $\mathrm{LUMO}_{\text {dipole }}-\mathrm{HOMO}_{\text {dipolarophile }}$ gap and therefore the dominant FMO approach is $\mathrm{HOMO}_{\text {dipole }}-\mathrm{LUMO}_{\text {dipolaro- }}$ phile. Both the HOMO and the LUMO of the dipole show uneven distribution of the electron density along the C-N-C dipole. In the HOMO case, the orbital coefficient is larger at $C_{1}(0.288)$ than at $C_{2}(-0.163)$. Similarly in the LUMO of methyl acrylate the atomic orbital coefficient are (0.611) and (-0.521) respectively (Figure 3 ). Thus it may be concluded that there is better overlap when -COOMe group lies towards thioisatin ring, giving two possibilities $\mathbf{5} \mathbf{a}$ and $\mathbf{5} \mathbf{b}$. Out of these $\mathbf{5 a}$ is formed in diastereomeric excess probably due to the endo approach of -COOMe.

\subsection{Regioselectivity of the addition of symmetrical and} unsymmetrical acetylenes

Parallel to methyl acrylate, diphenylacetylene can also attack either of the azomethine ylide $\left(\mathbf{4}_{s y n}\right.$ or $\left.\mathbf{4}_{\boldsymbol{a n t i}}\right)$ with the formation of products having two chiral centers. Therefore a total of $4+4=8$ isomers ( 4 pairs of enantiomers) could be possible 8a-8h (Figure 5).

Attack of diphenylacetylene on syn-azomethine ylide $\mathbf{4}_{s y n}$ results in the inward movement of the thiazolidine ring towards the thioisatin nucleus and the transition state could not be located even in a single case (Figure 2) ruling out the possibility of the formation of products $\mathbf{8 e - 8 h}$. Thus it leaves the possibility of attack on the anti azomethine ylide $\mathbf{4}_{a n t i}$ and hence only four isomers 8a-8d are left for consideration. We have optimized the geometry of all the four isomers. Results show that all isomers have almost same $\Delta H_{\mathrm{f}}$, indicating that thermodynamically all are nearly equally stable.

Of remaining four possibilities $\mathbf{8 c}$ and $\mathbf{8 d}$ where $\mathrm{N}$ and $\mathrm{H}$ atoms on the adjacent carbon atoms do not lie on the same side, the transition state could not be located because concerted mechanism is not possible in such a situation. This leaves only two isomers $\mathbf{8 a - 8 b}$ for consideration. Out of these two isomers we could optimize the transition state in case of 8a only (Figure 6). This can be explained using the FMO approach along with the endo approach of the phenyl ring (Figure 7) as discussed above.

Similarly attack of unsymmetrical dipolarophile, such as ethyl phenyl propiolate, on syn or anti azomethine ylide may produce a cycloadduct having two chiral centres and therefore a total of $4+4=8$ stereoisomers 9 a9h could be possible (Figure 8 ) and it was concluded that isomer $\mathbf{9 a}$ is formed preferentially (Figure 9). The energy profile diagrams for azabicycloadducts 5-9 are presented in (Figure 10).

$\Delta \mathrm{H}_{f-\mathrm{R}}, \Delta \mathrm{H}_{f-\mathrm{Ts}}, \Delta \mathrm{H}_{f-\mathrm{P}}, \mathrm{Ea}$ (activation energy) and stabilization energy of amy with different dipolarophiles have been tabulated in Table 2 . 


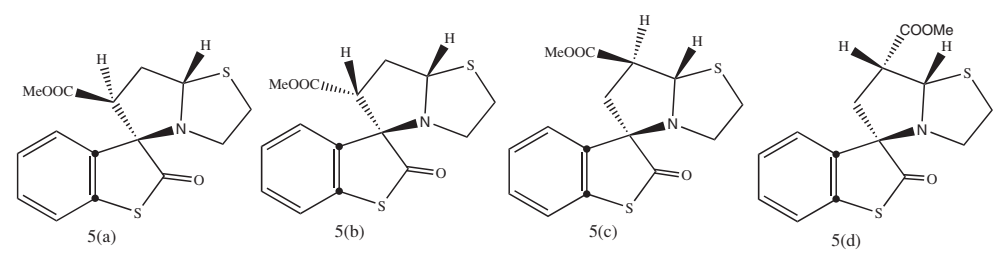<smiles>CC(=O)[C@H]1C[C@H]2SCCN2[C@@]12C(=O)Sc1ccccc12</smiles><smiles>CO[C@H]1C[C@H]2SCCN2[C@@]12C(=O)Sc1ccccc12</smiles><smiles>CC(=O)O[C@H]1C[C@@]2(C(=O)Sc3ccccc32)N2CCS[C@H]12</smiles>

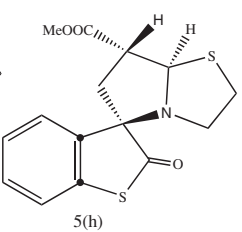<smiles>CC(C)C1(c2ccccc2O)C(C)(C)CC1(C)C</smiles><smiles>CC(C)C1(c2ccccc2N)C(C)(C)CC1(C)C</smiles>

$5(\mathrm{~g})$

5 (h)<smiles>C[C@H](O)[C@]1(C)C[C@]2(C(=O)Sc3ccccc32)c2ccccc21</smiles><smiles>C[C@]1(O)C[C@]2(C(=O)Nc3ccccc32)N2CCS[C@@]21C</smiles>

$5(\mathrm{i})$

$5(\mathrm{j})$

$5(\mathrm{k})$

$5(1)$<smiles>CO[C@H]1C[C@H]2SCCN2[C@]12C(=O)Sc1ccccc12</smiles><smiles>CO[C@H]1C[C@H]2SCCN2[C@@]12C(=O)Sc1ccccc12</smiles>

$5(\mathrm{n})$<smiles>C[C@H]1C[C@@]2(C(=O)Sc3ccccc32)N2CCS[C@H]12</smiles>

$5(0)$<smiles>CC(=O)[C@H]1C[C@]2(C(=O)Sc3ccccc32)N2CCS[C@H]12</smiles>

$5(\mathrm{p})$
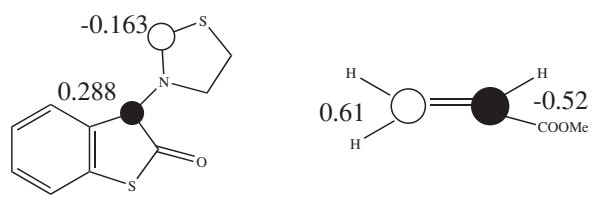

Atomic orbital coefficient of HOMO amy and LUMO methyl acrylate

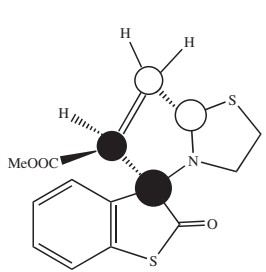

5 a

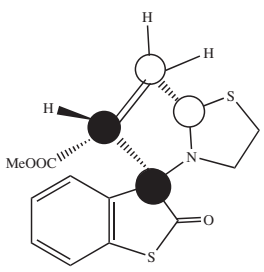

5b

Figure 3 Possible isomers of cycloadduct 5 and its regioselectivity. 


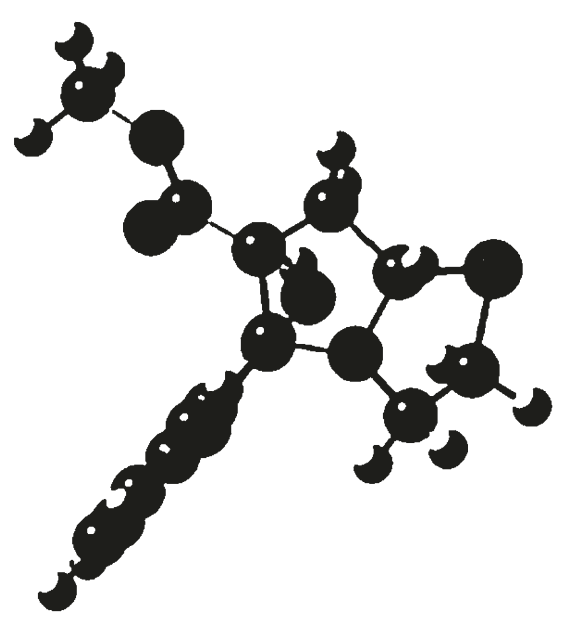

$5 a$

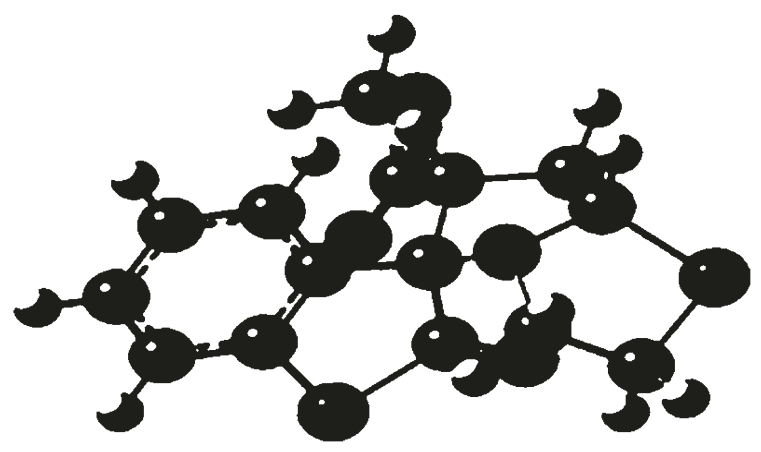

$5 b$

Figure 4 Transition states of cycloadducts $5 \mathrm{a}$ and $\mathbf{5 b}$.

\section{Conclusions}

From the above discussions, it may be concluded that:

a.The azomethine ylide exits in two conformations; $\mathbf{4}_{\text {syn }}$ and $\mathbf{4}_{\text {anti }}$.

b. The dominant FMO approach is $\mathrm{HOMO}_{\text {dipole }}{ }^{-}$ $\mathrm{LUMO}_{\text {dipolarophile }}$ as this energy gap is lower than the $\mathrm{LUMO}_{\text {dipole }}-\mathrm{HOMO}_{\text {dipolarophile }}$ gap.

c. Azomethine ylide is stabilized by the delocalization of dipolar charge into thioisatin nucleus, thus increasing the activation energy for the reaction path.

\section{Experimental}

The uncorrected melting points were taken in open glass capillaries. The IR spectra were recorded on a Nicolet Magna IR Spectrometer Model 550 in KBr pellets and band positions are reported in wave numbers $\left(\mathrm{cm}^{-1}\right)$. The ${ }^{1} \mathrm{H}$ NMR spectra and ${ }^{13} \mathrm{C}$ NMR spectra have been recorded on a Bruker DRX-300 MHz and $75.47 \mathrm{MHz}$ model respectively in $\mathrm{CDCl}_{3}$ and DMSO using tetramethylsilane as an internal standard. The chemical shifts are given in $\delta$ ppm values. The mass spectra were recorded on a JEOL-SX 102 (FAB). Most of the spectra were recorded at CDRI, Lucknow, India. Elemental analyses were performed on a Perkin Elmer

Table $1 \Delta \mathrm{H}_{\mathrm{f}}, \mathrm{HOMO}$, LUMO, energies and H-L And L-H energy gaps

\begin{tabular}{lllll}
\hline Cycloadduct & 5a & 5b & 5c & 5d \\
\hline$\Delta H_{\mathrm{f}}(\mathrm{Kcal} / \mathrm{mol})$ & 81.34 & 82.98 & 82.86 & 82.68 \\
\hline
\end{tabular}

Series C, H, N, S Analyzer 2400. The solvents were purified by standard procedures $[18,19]$. Acetonitrile was dried by refluxing with anhydrous calcium chloride for 5-6 $\mathrm{h}$ and then distilling it. Column chromatography was performed on silica gel 60 (Merck).

\section{Methods}

Synthesis of (5S,7R,8R)-spiro-\{7-methoxycarbonyl-1-aza-4thia-bicyclo $[3,3,0]$-octane $\left.8,3^{\prime}\right\}$-benzo[b]thiophene-2'one (5)

An equimolar mixture of thiosatin 1 (0.36 gm, 2.0 $\mathrm{mmol}$ ), thiazolidine-2-carboxylic acid 2 (0.26 gm, 2.0 $\mathrm{mmol})$ and methyl acrylate $(0.32 \mathrm{gm}, 2.0 \mathrm{mmol})$ in dry acetonitrile $(50 \mathrm{ml})$ was refluxed for $22 \mathrm{~h}$. The reaction was monitored by TLC until the consumption of the reactants. The reaction mixture was filtered, solvent evaporated and the residue was subjected to column chromatography. The petroleum ether/chloroform (4:1) fraction afforded the desired azabicycloadduct $\mathbf{5}$ as pale brown solid.

Pale brown solid, yield: $0.33 \mathrm{~g}(70 \%), \mathrm{mp}: 105-107^{\circ} \mathrm{C}$. IR $(\mathrm{KBr}): 1710(\mathrm{C}=\mathrm{O}), 1450(\mathrm{C}-\mathrm{N}), 715(\mathrm{C}-\mathrm{S}) \mathrm{cm}^{-1} \cdot{ }^{1} \mathrm{H}$ NMR $(\mathrm{CDCl} 3, \delta \mathrm{ppm}):=2.29(1 \mathrm{H}, \mathrm{t}, J=3.0 \mathrm{~Hz} 7-\mathrm{CH}), 2.46(2 \mathrm{H}$, $\left.\mathrm{dd}, J_{1}=4.2 \mathrm{~Hz}, J_{2}=3.3 \mathrm{~Hz} 6-\mathrm{CH}_{2}\right), 2.50(2 \mathrm{H}, \mathrm{t}, J=1.2 \mathrm{~Hz}$ $\left.3-\mathrm{CH}_{2}\right), 2.68\left(2 \mathrm{H}, \mathrm{t}, \mathrm{J}=2.1 \mathrm{~Hz} 2-\mathrm{CH}_{2}\right), 3.10\left(3 \mathrm{H}, \mathrm{s}, \mathrm{OCH}_{3}\right)$, $4.15(1 \mathrm{H}, \mathrm{t}, J=3.54 \mathrm{~Hz}, 5-\mathrm{CH}), 7.36-7.54(4 \mathrm{H}, \mathrm{m}, \mathrm{ArH})$. ${ }^{13} \mathrm{C} \mathrm{NMR}(\mathrm{CDCl} 3, \delta \mathrm{ppm}): 35.43\left(\mathrm{CH}_{2} \mathrm{~S}\right), 44.58\left(\mathrm{CH}_{2}\right)$, 46.34 (CH), 85.99(C-N), 125.86-124.32(C = C), 142.58131.36(CHaro), 175.67(O = C-O), 184.32(C = O). EI-MS: $\mathrm{m} / \mathrm{z}(\%)=321(\mathrm{M}+38), 275(100), 261(20), 284(15), 234$ (18). Anal. Calcd. For $\mathrm{C}_{15} \mathrm{H}_{15} \mathrm{NO}_{3} \mathrm{~S}_{2}$ : C, 56.05\%; H, 4.70\%; N, 4.36\%. Found: C, 56.45\%; H, 4.78\%; N, 4.76\%. 
<smiles>NCCS[C@@H]1C(c2ccccc2)=C(c2ccccc2)[C@@]12C(=O)Sc1ccccc12</smiles>

8a<smiles>O=C1Sc2ccccc2[C@]12C(c1ccccc1)=C[C@H]1SCCN12</smiles>

8d<smiles>O=C1Sc2ccccc2[C@]12C(c1ccccc1)=C[C@H]1SCCN12</smiles>

$8 b$<smiles>O=C1Sc2ccccc2[C@]12C(c1ccccc1)=C(c1ccccc1)[C@H]1CSCN12</smiles>

8e<smiles>O=C1Sc2ccccc2[C@]12C(c1ccccc1)=C(c1ccccc1)[C@@H]1SCCN12</smiles>

8c<smiles>O=C1Sc2ccccc2[C@]12C(c1ccccc1)[C@H]1CSCN12</smiles>

$8 f$<smiles>O=C1Sc2ccccc2[C@]12C(c1ccccc1)C(c1ccccc1)[C@H]1CSCN12</smiles>

$8 g$<smiles>O=C1Sc2ccccc2[C@]12C(c1ccccc1)C(c1ccccc1)[C@H]1CSCN12</smiles>

$8 h$

Figure 5 Possible isomers of cycloadduct 8.

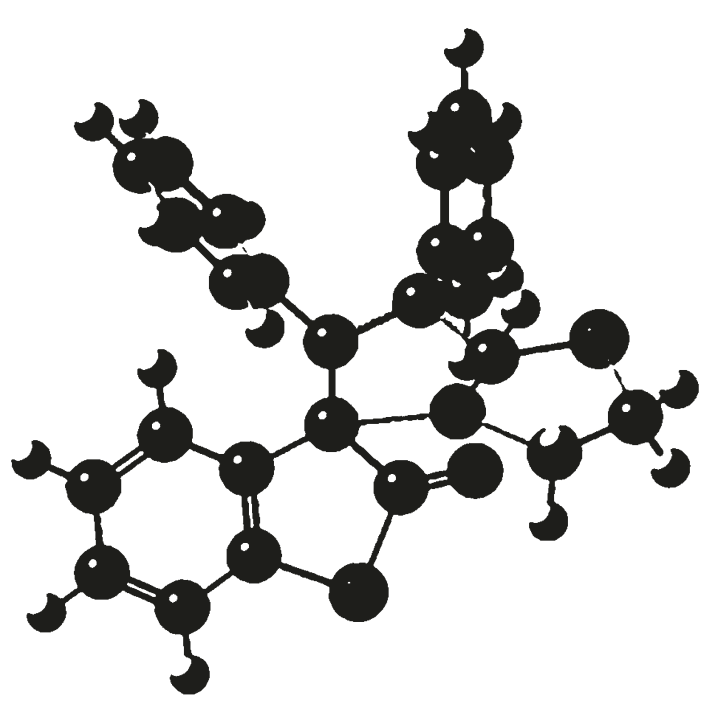

Figure 6 Transition state of diphenylacetylene cycloadduct 8 .
(5R,8R)-spiro-\{7-phenyl-1-aza-4-thia-bicyclo [3,3,0]-6octene-8,3'\}-benzo[b] thiophene-2'-one (6)

Coffee brown powder, yield: $0.31 \mathrm{~g}(65 \%), \mathrm{mp}: 95-97^{\circ} \mathrm{C}$. IR $(\mathrm{KBr}): 1720(\mathrm{C}=\mathrm{O}), 1445(\mathrm{C}-\mathrm{N}), 690(\mathrm{C}-\mathrm{S}) \mathrm{cm}^{-1} \cdot{ }^{1} \mathrm{H}$ $\mathrm{NMR}(\mathrm{CDCl} 3, \delta \mathrm{ppm}):=2.50\left(2 \mathrm{H}, \mathrm{t}, J=3.0 \mathrm{~Hz}, 3-\mathrm{CH}_{2}\right)$, $2.68\left(2 \mathrm{H}, \mathrm{t}, J=3.3 \mathrm{~Hz}, 2-\mathrm{CH}_{2}\right), 4.12(1 \mathrm{H}, \mathrm{d}, J=2.4 \mathrm{~Hz}, 5-$ $\mathrm{CH}), 4.32(1 \mathrm{H}, \mathrm{d}, J=6.6 \mathrm{~Hz}, 6-\mathrm{CH}), 7.32-7.54(9 \mathrm{H}, \mathrm{m}$, $\mathrm{ArH}) .{ }^{13} \mathrm{C} \mathrm{NMR}(\mathrm{CDCl} 3, \delta \mathrm{ppm}): 31.51\left(\mathrm{CH}_{2} \mathrm{~S}\right), 36.54$ $\left(\mathrm{CH}_{2}\right), 45.46(\mathrm{CH}), 85.95(\mathrm{C}-\mathrm{N}), 128.81-124.49(\mathrm{C}=\mathrm{C})$, 143.87-132.36(CHaro), 180.79 $(\mathrm{C}=\mathrm{O})$. EI-MS: $\mathrm{m} / \mathrm{z}(\%)=$ 337(M+ 36), 203(100), 309(20), 108(34). Anal.Calcd for $\mathrm{C}_{19} \mathrm{H}_{15} \mathrm{NOS}_{2}$ : C, 67.62\%; H, 4.48\%; N, 4.15\%. Found: C, $67.78 \%$; H, 4.53\%; N, 4.32\%.

\section{(5R,8R)-spiro-\{7-phenyl-6-methyl-1-aza-4-thia-bicyclo} [3,3,0]-6-octene-8,3'\}- benzo[b]thiophene-2'-one (7) Brownish solid, yield: $0.32 \mathrm{~g}(68 \%), \mathrm{mp}: 120-122^{\circ} \mathrm{C}$. IR (KBr): $1725(\mathrm{C}=\mathrm{O}), 1420(\mathrm{C}-\mathrm{N}), 678(\mathrm{C}-\mathrm{S}) \mathrm{cm}^{-1} \cdot{ }^{1} \mathrm{H}$ NMR $(\mathrm{CDCl} 3, \delta \mathrm{ppm}): 2.14(3 \mathrm{H}, \mathrm{d}, J=7.2 \mathrm{~Hz}, \mathrm{Me}), 2.50(2 \mathrm{H}, \mathrm{t}$, $\left.J=3.0 \mathrm{~Hz} 3-\mathrm{CH}_{2}\right), 2.68\left(2 \mathrm{H}, \mathrm{t}, J=3.2 \mathrm{~Hz} 2-\mathrm{CH}_{2}\right), 2.84(1 \mathrm{H}$, 


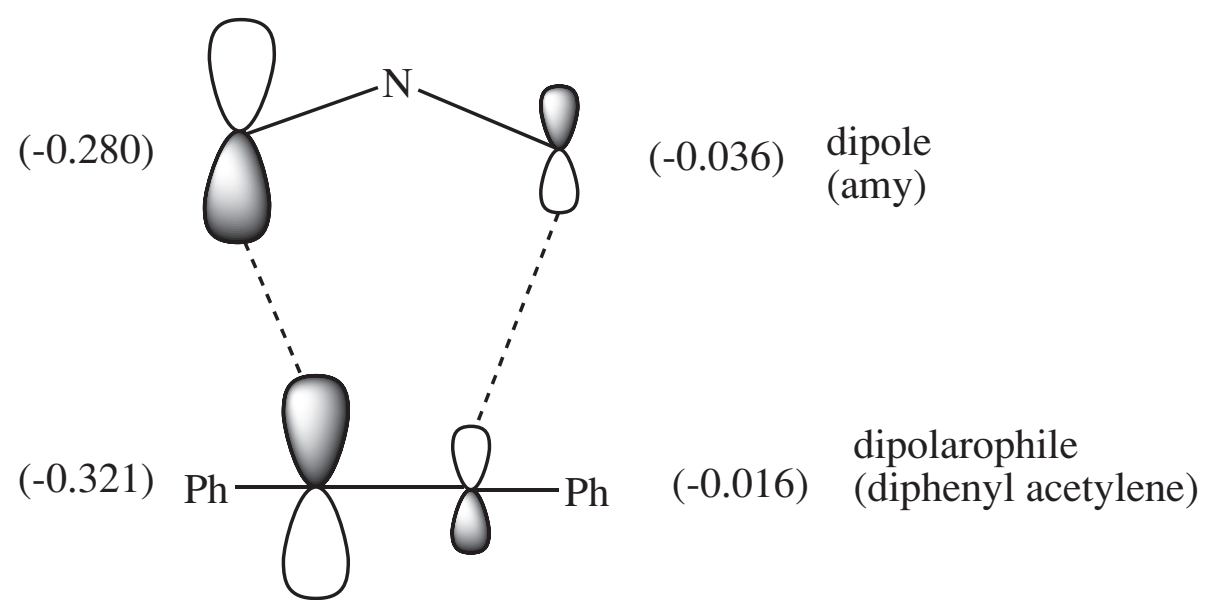

Figure 7 Atomic orbital coefficients and overlapping of dipole(amy) with diphenylacetylene.<smiles>CCOC(=O)C1=C([PH2+]c2ccccc2)[C@@]2(C(=O)Sc3ccccc32)N2CCS[C@H]12</smiles>

9a<smiles>CCOC(=O)C1=C(c2ccccc2)[C@@H]2SCCN2[C@]12C(=O)Sc1ccccc12</smiles>

9d<smiles>CCOC(=O)C1=C(c2ccccc2)[C@@H]2SCCN2C12C(=O)Sc1ccccc12</smiles>

$9 \mathbf{b}$<smiles>CCOC(=O)C1=C(c2ccccc2)[C@@H]2CSC[C@H]2N1C(=O)Sc1ccccc1</smiles>

9 e<smiles>CCOC(=O)C1=C(c2ccccc2)[C@@]2(C(=O)Sc3ccccc32)[C@@H]2SCCN12</smiles>

9c<smiles>CCOC(=O)C1=C(c2ccccc2)[C@@H]2CSCN2[C@]12C(=O)Sc1ccccc12</smiles>

9f<smiles>CCOC(=O)C1=C(c2ccccc2)[C@@H]2CSCN2[C@@]12C(=O)Sc1ccccc12</smiles><smiles>CCOC(=O)[C@H]1[C@H](c2ccccc2)[C@@H]2CSCN2[C@@]12C(=O)Sc1ccccc12</smiles>

9h 


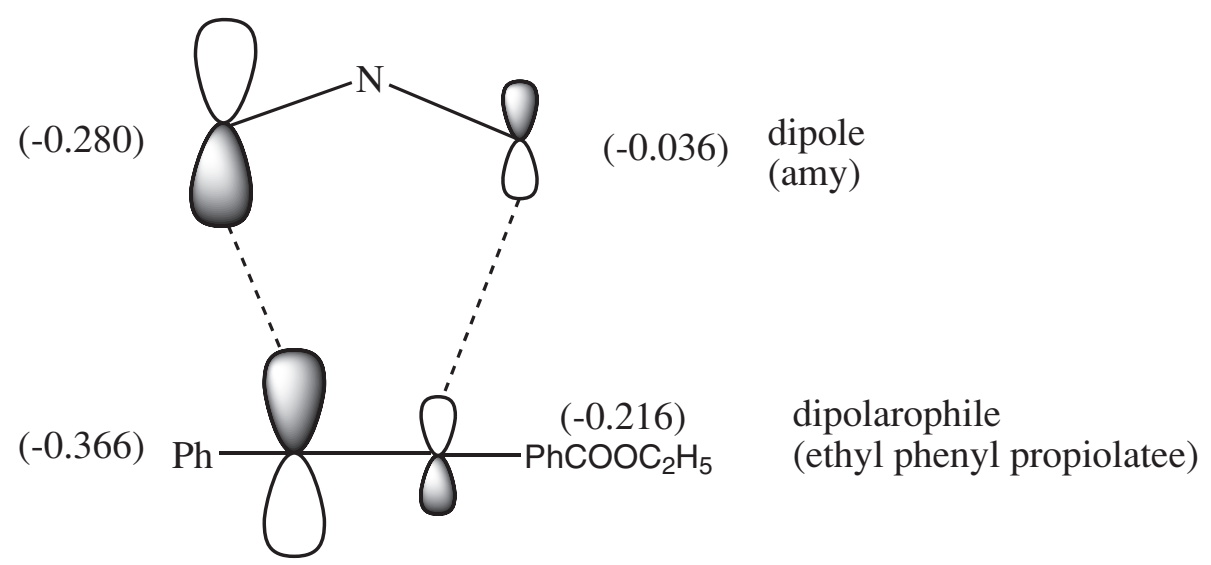

Figure 9 Atomic orbital coefficients and overlapping of amy with ethylphenyl propiolate

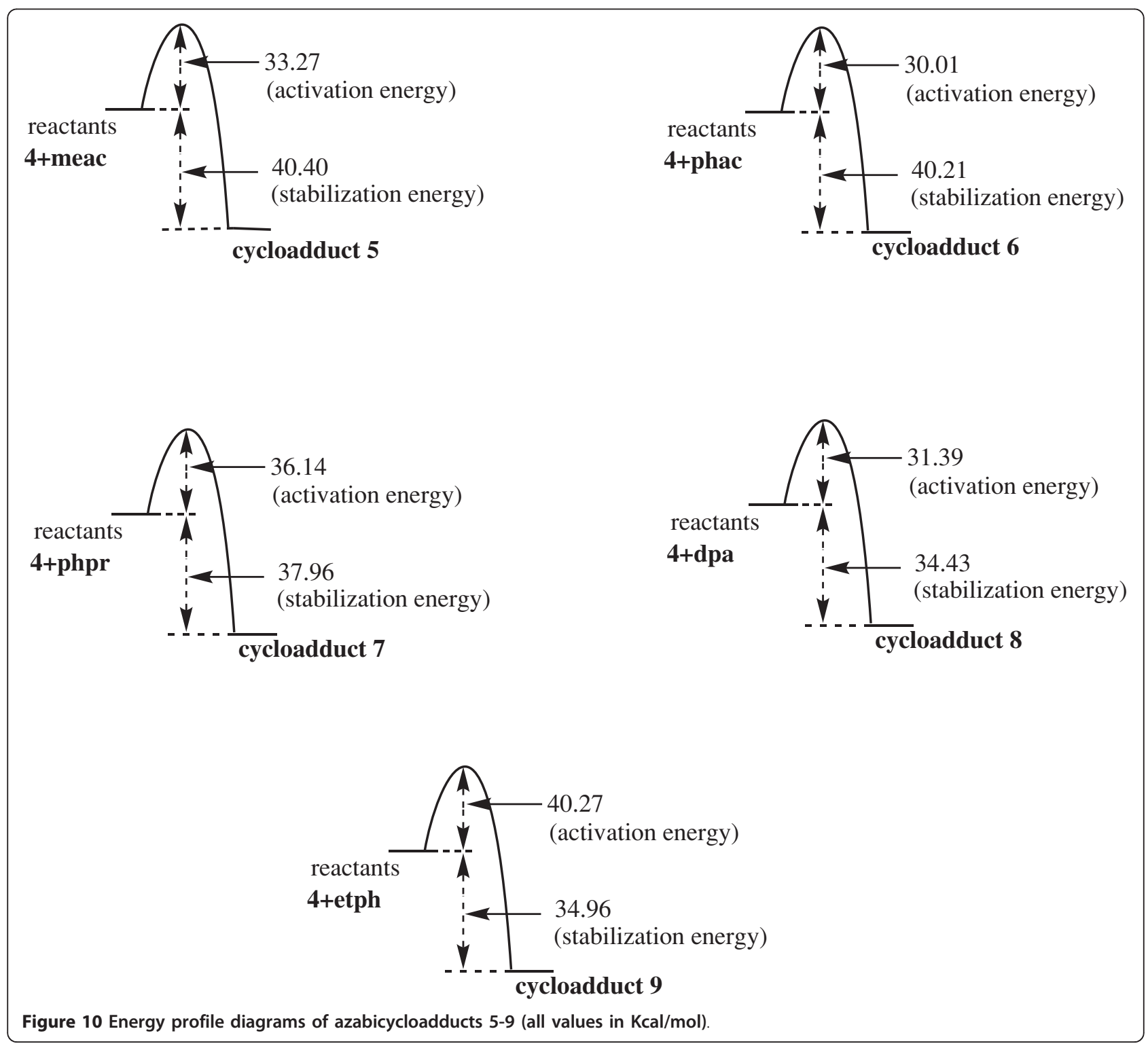


Table $2 \Delta \mathrm{H}_{\mathrm{f}}-\mathrm{R}, \Delta \mathrm{H}_{\mathrm{f}}-\mathrm{Ts}, \Delta \mathrm{H}_{\mathrm{f}}-\mathrm{P}, \mathrm{Ea}$. and stabilization energy of amy with different dipolarophiles

\begin{tabular}{lllll}
\hline Cycloadduct & $\mathbf{8 a}$ & $\mathbf{8 b}$ & $\mathbf{8 c}$ & $\mathbf{8 d}$ \\
\hline$\Delta \mathrm{H}_{\mathrm{f}}(\mathrm{Kcal} / \mathrm{mol})$ & 109.38 & 112.32 & 109.86 & 110.38 \\
\hline
\end{tabular}

$\mathrm{q}, J=3.6 \mathrm{~Hz}, 5-\mathrm{CH}), 7.59-8.45(9 \mathrm{H}, \mathrm{m}, \mathrm{ArH}) .{ }^{13} \mathrm{C} \mathrm{NMR}$ (CDCl3, $\delta \mathrm{ppm}): 32.33\left(\mathrm{CH}_{2} \mathrm{~S}\right), 35.43\left(\mathrm{CH}_{2}\right), 44.45(\mathrm{CH})$, 86.54 $(\mathrm{C}-\mathrm{N}), 124.23-122.86(\mathrm{C}=\mathrm{C}), 143.41-130.63$ (CHaro), 184.34 $(\mathrm{C}=\mathrm{O})$. Anal.Calcd for $\mathrm{C}_{20} \mathrm{H}_{17} \mathrm{NOS}_{2}$ : C, 68.34\%; H, 4.87\%; N, 3.98\%. Found: C, 68.55\%; H, 4.93\%; $\mathrm{N}, 4.13 \%$.

(5R,8R)-spiro-\{6,7-diphenyl-1-aza-4-thia-bicyclo [3,3,0]-6octene 8, 3'\}- benzo[b]thiophene-2'-one (8)

Shiny brown powder, yield: $0.29 \mathrm{~g}(63 \%), \mathrm{mp}: 135-133^{\circ} \mathrm{C}$. IR (KBr): $1715(\mathrm{C}=\mathrm{O}), 1420(\mathrm{C}-\mathrm{N}), 6905(\mathrm{C}-\mathrm{S}) \mathrm{cm}^{-1} \cdot{ }^{1} \mathrm{H}$ NMR (CDCl3, $\delta \mathrm{ppm}): 2.51\left(2 \mathrm{H}, \mathrm{t}, J=2.7 \mathrm{~Hz}, 3-\mathrm{CH}_{2}\right)$, $2.60\left(2 \mathrm{H}, \mathrm{t}, \mathrm{J}=3.0 \mathrm{~Hz}, 2-\mathrm{CH}_{2}\right), 4.15(1 \mathrm{H}, \mathrm{s}, 5-\mathrm{CH}) 6.79-$ 8.12(14H, m, ArH). ${ }^{13} \mathrm{C}$ NMR (CDCl3, $\left.\delta \mathrm{ppm}\right): 34.54$ $\left(\mathrm{CH}_{2} \mathrm{~S}\right), 45.43\left(\mathrm{CH}_{2}\right), 46.72(\mathrm{CH}), 88.23(\mathrm{C}-\mathrm{N}), 127.32-$ 126.54 $(\mathrm{C}=\mathrm{C}), 146.41-132.32$ (Caro), 183.54( $\mathrm{C}=\mathrm{O})$. EIMS: $\mathrm{m} / \mathrm{z}(\%)=413\left(\mathrm{M}^{+} 32\right), 385(39), 235(100), 108(35)$. Anal. Calcd for $\mathrm{C}_{25} \mathrm{H}_{19} \mathrm{NOS}_{2}$ : C, 72.61\%; H, 4.63\%; N, $3.39 \%$. Found: C, $72.73 \%$; $\mathrm{H}, 4.78 \%$; N, 3.86\%.

\section{(5R,8R)-spiro-\{6-ethoxycarbonyl-7-phenyl-1-aza-4-thia- bicyclo $[3,3,0]-6$-octene-8, 3'\}-benzo[b]thiophene-2'-one (9)}

Dark brown power, yield: $0.31 \mathrm{~g}(69 \%), \mathrm{mp}: 110-112^{\circ} \mathrm{C}$. IR (KBr): $1710(\mathrm{C}=\mathrm{O}), 1410(\mathrm{C}-\mathrm{N}), 690(\mathrm{C}-\mathrm{S}) \mathrm{cm}^{-1} \cdot{ }^{1} \mathrm{H}$ NMR (CDCl3, $\delta \mathrm{ppm}): 1.25(3 \mathrm{H}, \mathrm{t}, J=2.4 \mathrm{~Hz} \mathrm{Me}), 2.61$ $\left(2 \mathrm{H}, \mathrm{t}, J=2.9 \mathrm{~Hz} 3-\mathrm{CH}_{2}\right), 2.69\left(2 \mathrm{H}, \mathrm{t}, J=3.1 \mathrm{~Hz}, 2-\mathrm{CH}_{2}\right)$, $2.67\left(2 \mathrm{H}, \mathrm{t}, \mathrm{CH}_{2}\right), 3.75\left(2 \mathrm{H}, \mathrm{q}, J=6.3 \mathrm{~Hz}, \mathrm{OCH}_{2}\right), 4.12(1 \mathrm{H}$. s,5-CH) 7.49-7.94(4H, m, ArH). ${ }^{13} \mathrm{C} \mathrm{NMR}\left(\mathrm{CDCl}_{3}, \delta\right.$ ppm): 33.85 $\left(\mathrm{CH}_{2}\right), 44.96(\mathrm{CH}), 46.32\left(\mathrm{CH}_{2}\right), 84.36(\mathrm{C}-\mathrm{N})$, 124.32-122.93(C = C), 140.14-130.12(CHaro), 180.25(O $=\mathrm{C}-\mathrm{O}), 185.44(\mathrm{C}=\mathrm{O})$. EI-MS: $\mathrm{m} / \mathrm{z}(\%)=321(\mathrm{M}+38)$, 275(100), 261(20), 284(15), 234(18). Anal. Calcd for $\mathrm{C}_{22} \mathrm{H}_{19} \mathrm{NO}_{3} \mathrm{~S}_{2}$ : C, 64.52\%; H, 4.68\%; N, 3.42\%. Found: C, 64.68\%; H, 4.79\%; N, 3.54\%.

\section{Acknowledgements \\ Financial assistance from UGC New Delhi (Project No.36-289/2008(SR)) is gratefully acknowledged. Sonali Verma also thanks UGC for RGN-SRF.}

\section{Competing interests}

The authors declare that they have no competing interests.

Received: 18 March 2011 Accepted: 6 September 2011 Published: 6 September 2011

\section{References}

1. Katritzky AR, Ramsden CA (2008) Comprehensive Heterocyclic Chemistry III. In: Scriver EFV, Taylors RJK(eds) Elsevier, New York
2. Harwood LM, Vickers RJ (2003) In synthetic applications of 1,3-dipolar cycloadditions chemistry toward heterocycles and natural products. In: Padwa A, Pearson WH(eds) Wiley, New York, p 169

3. Gothelf KV, Kobayashi S, Jorgensen KA (eds) (2002) In cycloaddition reactions in organic synthesis. Wiley- $\mathrm{VCH}$, Weinheim, Germany, p 211

4. $\quad$ Zang H, Chan WH, Lee AWM, Xia P-F, Wong WY (2004) Asymmetric 1,3dipolar cycloaddition of chiral $\alpha, \beta$-unsaturated- $\gamma$-sultams with nitrile oxides and nitrones. Lett Org Chem 1:63-66. doi:10.2174/1570178043488644.

5. Najera C, Sansano JM (2009) 1,3-Dipolar cycloaddition reactions of metal stabilized azomethine ylides. Org Biomol Chem 7:4567-4581. doi:10.1039/ b913066g.

6. Pandey G, Banerjee P, Gadre SR (2006) Asymmetric 1,3-dipolar cycloaddition reactions of metal stabilized azomethine ylides. Chem Rev 106:4484-4517. doi:10.1021/cr050011g.

7. Girgis AS (2009) Regioselective synthesis of dispiro[1H-indene-2, 3'pyrrolidine-2', 3"-[3H]indole]-1, 2"[1"H]-diones of potential anti-tumour properties. Euro J Chem 44:91-100

8. Tsuge O, Kanesmasa S (1993) In Advances in Cycloaddition. In: Curran DP (eds) Jai Press, Greenwich, CT,3: p 99

9. Poornachandran M, Jayagobi M, Ragunathan R (2009) Synthesis of novel spiropyrrolizidines as potent antimicrobial agents for human and plant pathogens. J Chem Res 4:240-243

10. Liang Y, Song YZX (2009) Phosphine- and water- cocatalyzed [3 + 2] cycloaddition reactions of 2-Methyl-2,3-butadienoate with fumarates: $A$ computational and experimental study. Synlett 6:905-909

11. Rajopadhye M, Popp FD (1988) Chemistry of benzo[b]thiophene-2,3- dione. Heterocycles 27:1489-1502. doi:10.3987/REV-87-382.

12. Navarro A, Sanchez Pino M-J, Gomez C, Bandez MJ, Cadenas E, Boveris A (2007) Dietary thioproline decreases spontaneous food intake and increases survival and increases neurological function in mice. Antioxid Redox Signal 9:131-141. doi:10.1089/ars.2007.9.131.

13. Li C, Han BY, Wanshun L (2007) Antioxidant activity of N-acetyl glucosamine based thiazolidine derivative. High Tech Lett 13:441-445

14. Padwa A (1984) 1,3-Dipolar Cycloaddition Chemistry. Wiley, New York

15. Arora K, Jose D, Singh D, Gupta RS, Pardasani P, Pardasani RT (2009) Stereoselective synthesis and antioxidant activity of azabicycloadducts derived from9, 10-phenanthrenequinone. Heteroatom Chem 20:379-392

16. Frisch MJ, et al., (2004) GAUSSIAN 03(Revision B.03). Gaussian, Inc., Wallingford, CT

17. Amornraksa K, Grigg R, Gunaratne HQN, Kemp J, Sridharan V (1987) X:YZH Systems as potential 1, 3-dipoles. Part 8. Pyrrolidines and $\Delta^{5}$-pyrrolines(3, 7diazabicyclo[3.3.0]octenes) from the reaction of imines of a-amino acids and their esters with cyclic dipolarophiles. Mechanism of racemisation of aamino acids and their esters in the presence of aldehydes. J Chem Soc Perkin Trans 1:2285-2296

18. Perrin DD, Armarego WLF, Perrin DR (1998) Purification of Laboratory Chemicals. $2^{\text {nd }}$ ed, Pergamon Press, Oxford

19. Vogel Al (1984) Vogel's Text Book of Practical Organic Chemistry. $4^{\text {th }}$ ed, ELBS Longman, London

doi:10.1186/2191-2858-1-6

Cite this article as: Verma et al:: [3 + 2] Cycloaddition reactions of thioisatin with thiazolidine-2-carboxylic acid: a versatile route to new heterocyclic scaffolds. Organic and Medicinal Chemistry Letters 2011 1:6.

\section{Submit your manuscript to a SpringerOpen ${ }^{\circ}$ journal and benefit from:}

- Convenient online submission

- Rigorous peer review

- Immediate publication on acceptance

- Open access: articles freely available online

- High visibility within the field

- Retaining the copyright to your article

Submit your next manuscript at $>$ springeropen.com 